\title{
TINGKAT PENGETAHUAN MAHASISWA PROGRAM STUDI PENDIDIKAN DOKTER TERHADAP KURIKULUM TERSEMBUNYI
}

\author{
Sari Fadila ${ }^{1}$, Syarifah Nora Andriaty ${ }^{1}$, Ade Kiki Riezky ${ }^{1}$ \\ ${ }^{1}$ Program Studi Pendidikan Dokter, Fakultas Kedokteran, Universitas Abulyatama
}

\begin{abstract}
The Level of Understanding of Medical Education Study Program Students towards The Hidden Curriculum. The hidden curriculum is an implicit curriculum, a series of unwritten, unofficial, and unintended lessons, values and perspectives that are learned in education. The hidden curriculum in the educational process encourages the formation of professionalism, ethics, altruism, empathy, and leadership which are competencies that students must possess. The purpose of this study was to determine the level of understanding of medica I education study program students towards the hidden curriculum at the Faculty of Medicine, Abulyatama University. This type of research is a quantitative descriptive study with a cross sectional research design. Data collection was done by filling out a questionnaire sheet. The sample in this study were 167 preclinical and clinical students of the medical education study program, who were determined by purposive sampling technique. Data analysis was performed using univariate analysis to obtain a description of the frequency of each variable in the form of academic status, gender and level of professionalism, altruism, ethics, empathy and leadership. The results showed that based on academic status, the distribution of pre-clinic student respondents was $136(81.4 \%)$ and clinic $31(18.6 \%)$. Distribution based on gender, namely male $51(30.5 \%)$, and female $116(69.5 \%)$. The distribution of understanding of the hidden curriculum among pre-clinical students shows $100 \%$ for aspects of professionalism and empathy, $98.5 \%$ for aspects of ethics and altruism, and $97 \%$ for aspects of leadership. Clinical students showed $100 \%$ for aspects of professionalism, ethics, altruism, and empathy, and $87 \%$ for aspects of leadership. The conclusion is that preclinical students and clinical students of the medical education study program have a good understanding of the hidden curriculum.
\end{abstract}

Keywords: thehidden curriculum, professionalism, ethics, altruism, empathy, leadership

\begin{abstract}
Abstrak: Tingkat Pengetahuan Mahasiswa Program Studi Pendidikan Dokter Terhadap Kurikulum Tersembunyi. Kurikulum tersembunyi merupakan kurikulum implisit, serangkaian pelajaran, nilai, dan perspektif yang tidak tertulis, tidak resmi, dan tidak disengaja yang dipelajari dalam pendidikan. Kurikulum tersembunyi dalam proses pendidikan mendorong agar terbentuknya profesionalisme, etika, altruisme, empati, dan kepemimpinan yang merupakan kompetensi yang harus dimiliki oleh mahasiswa. Tujuan dari penelitian ini adalah untuk mengetahui tingkat pemahaman mahasiswa program studi pendidikan dokter terhadap kurikulum tersembunyi di Fakultas Kedokteran Universitas Abulyatama. Jenis penelitian ini adalah penelitian deskriptif kuantitatif dengan desain penelitian cross sectional. Pengumpulan data dilakukan melalui pengisian lembar kuesioner. Sampel dalam penelitian adalah mahasiswa preklinik dan klinik program studi pendidikan dokter yang berjumlah 167 orang yang ditentukan dengan teknik purposive sampling. Analisis data dilakukan dengan analisis univariat untuk memperoleh deskripsi frekuensi pada setiap variabel berupa status akademik, jenis kelamin dan tingkat profesionalisme, altruisme, etika, empati dan kepemimpinan. Hasil penelitian menunjukkan bahwa berdasarkan status akademik, diperoleh distribusi responden mahasiswa pre-klinik 136 (74.3\%) dan klinik 31 (16.9\%). Distribusi berdasarkan jenis kelamin yaitu laki-laki $51(30.5 \%)$, dan perempuan
\end{abstract}


116(69.5\%). Distribusi pemahaman tentang kurikulum tersembunyi pada mahasiswa pre-klinik menunjukkan $100 \%$ untuk aspek profesionalisme dan empati, 98.5\% untuk aspek etika dan altruisme, serta 97\% untuk aspek kepemimpinan. Pada mahasiswa klinik menunjukkan $100 \%$ untuk aspek profesionalisme, etika, altruisme, dan empati, serta $87 \%$ untuk aspek kepemimpinan. Pada responden alumni menunjukkan $100 \%$ untuk seluruh aspek. Kesimpulannya bahwa mahasiswa preklinik dan klinik program studi pendidikan dokter memiliki pemahaman yang baik terkait kurikulum tersembunyi.

Kata Kunci: Kurikulum tersembunyi, profesionalisme, etika, altruisme, empati, kepemimpinan

\section{PENDAHULUAN}

Kurikulum adalah inti dari proses pendidikan berbentuk acuan, rencana, dan norma-norma yang bisa digunakan sebagai pegangan dalam proses pendidikan. Secara umum kurikulum memiliki empat komponen utama, yaitu: tujuan, materi/bahan, proses belajar mengajar dan evaluasi (Nurdin, 2018).Kurikulum merupakan suatu rencana yang disusun untuk menjalankan proses belajar mengajar di bawah bimbingan dan tanggung jawab suatu lembaga pendidikan, kurikulum bukan hanya mencakup semua kegiatan yang sudah disusun akan tetapi juga mengenai peristiwaperistiwa yang terjadi di dalam suatu lembaga pendidikan (Bahri, 2017).

Kurikulum pada tingkat pendidikan tinggi diartikan sebagai seperangkat rencana dan pengaturan mengenai capaian pembelajaran untuk kelulusan, proses, bahan kajian, dan penilaian yang digunakan sebagai pedoman penyelenggaraan program studi(Nurdin, 2018; Andriaty, et al., 2016). Secara umum kurikulum terbagi dua jenis, yaitu kurikulum formal berupa kurikulum yang tertulis dan kurikulum informal atau disebut juga kurikulum tersembunyi berupa kurikulum yang tidak tertulis (Bahri, 2017).

Kurikulum tersembunyi (hidden curriculum) merupakan kurikulum implisit yang menggambarkan dan mewakili sikap, perilaku, dan pengetahuan yang di komunikasikan tanpa sadar, semua itu disampaikan secara tidak langsung melalui kata-kata dan tindakan yang merupakan bagian dari kehidupan semua orang dalam

lingkup masyarakat (Alsubaie, 2015; Rajput,et al., 2017). Aspek-aspek yang terdapat pada kurikulum tersembunyi penting dalam pendidikan profesional (Gardeshi, et al., 2018). Kurikulum tersembunyi pertama kali dikenal pada tahun 1960-an di Amerika. Penerapannya pada pendidikan kedokteran dimulai pada tahun 1994 (Hafferty, et al., 2015). Pada profesi kedokteran kurikulum tersembunyi atau disebut juga sebagai kurikulum informal merupakan lingkup budaya pendidikan di kedokteran yang lebih luas dan terjadi di luar instruksi formal.

Kurikulum tersembunyi dapat berjalan paralel dengan kurikulum formal dan merupakan proses sosialisasi kompleksitas dokter dengan pasien, dokter dengan tim interprofesional dan hubungan komunitas dokter(Lawrence, et al., 2018). Kurikulum tersembunyi diartikan sebagai serangkaian pelajaran, nilai, dan perspektif yang tidak tertulis, tidak resmi, dan tidak disengaja yang dipelajari mahasiswa pada pendidikan kedokteran untuk mencapai kompetensi tertentu (Gardeshi, et al., 2018). Kompetensi yang harus dicapai dan dimiliki seorang dokter meliputi area etika, moral, dan profesionalisme. Profesionalisme di masa lalu merupakan suatu pembelajaran kurikulum yang tidak tertulis atau disebut juga sebagai kurikulum tersembunyi (Phillips \& Clarke, 2012). Kurikulum tersembunyi tersusun atas beberapa komponen yang mengarahkan pada profesionalisme, etika, altruisme, empati, dan kepemimpinan yang juga merupakan 
kompetensi yang harus miliki oleh mahasiswa (Silveira, et al., 2019; Balboni, et al., 2015; Mossop, et al., 2013;).

Berdasarkan hasil penelitian sebelumnya terkait dengan kurikulum tersembunyi, ditemukan bahwa pemahaman mengenai kurikulum tersembunyi berpengaruh terhadap motivasi diri mahasiswa, dan tingginya motivasi sejalan dengan prestasi mahasiswa (Gunawan, et al., 2018). Hasil penelitian lainnya juga menunjukkan bahwa kurangnya pemahaman terkait kurikulum tersembunyi mengakibatkan komponen perkuliahan berjalan dengan kurang baik (Yahya, 2013). Pentingnya peranan kurikulum tersembunyi dalam pendidikan mendorong peneliti untuk mengkaji lebih lanjut terkait tingkat pemahaman mahasiswa pada program studi pendidikan dokter terhadap kurikulum tersembunyi.

\section{METODE}

Penelitian ini merupakan penelitian deskriptif kuantitatif dengan desain penelitian cross sectional. Penelitian ini bertujuan untuk mengetahui tingkat pemahaman mahasiswa pendidikan dokter terhadap kurikulum tersembunyi.

Penelitian dilaksanakan pada Februari-Juni tahun 2020 di Fakultas Kedokteran Universitas Abulyatama. Populasi yang dijadikan sampel dalam penelitian yaitu mahasiswa preklinik dan mahasiswa klinik program pendidikan dokter. Penentuan sampel dilakukan dengan menggunakan teknik purposive sampling.

Variabel yang diteliti terdiri atas variabel dependen, yaitu populasi mahasiswa yang menjadi sampel penelitian, dan variabel independen, yaitu profesionalisme, etika, altruisme, empati, dan kepemimpinan.

Instrumen pengumpulan data dilakukan dengan menggunakan data primer berupa lembar kuesioner yang disusun dalam bentuk e-form dan dibagikan secara daring kepada mahasiswa yang menjadi sampel dalam penelitian.

Analisis data dalam penelitian dilakukan dengan analisis univariat untuk memperoleh deskripsi frekuensi pada setiap variabel berupa status akademik, jenis kelamin dan tingkat profesionalisme, altruisme, etika, empati dan kepemimpinan.

\section{HASIL}

1. Karakteristik Responden Berdasarkan Status Akademik

Distribusi karakteristik dari responden berdasarkan kategori status akademik berupa mahasiswa preklinik dan mahasiswa klinik yang diperoleh melalui pengisian kuesioner disajikan pada Tabel 1.

Tabel 1. Distribusi Karakteristik Responden Berdasarkan Kategori Status Akademik

\begin{tabular}{llcc}
\hline No & Kategori Status Akademik & N & Persentase (\%) \\
\hline 1 & Mahasiswa Preklinik & 136 & 81.4 \\
2 & Mahasiswa Klinik & 31 & 18.6 \\
\hline & Total & $\mathbf{1 6 7}$ & $\mathbf{1 0 0}$ \\
\hline
\end{tabular}

Berdasarkan tabel di atas menunjukkan bahwa kategori status akademik responden yang terbanyak berada dalam kategori mahasiswa preklinik sejumlah $136(81.4 \%)$, dan mahasiswa klinik sejumlah 31 (18.6\%), 
2. Karakteristik Berdasarkan jenis Kelamin Distribusi karakteristik dari responden berdasarkan kategori jenis kelamin yang diperoleh melalui pengisian kuesioner disajikan pada Tabel 2.

Tabel 2. Distribusi Karakteristik Responden Berdasarkan Kategori Jenis Kelamin

\begin{tabular}{llcc}
\hline No & Kategori Jenis Kelamin & N & Persentase (\%) \\
\hline 1 & Laki-laki & 51 & 30.5 \\
2 & Perempuan & 116 & 69.5 \\
\hline & Total & $\mathbf{1 6 7}$ & $\mathbf{1 0 0}$ \\
\hline
\end{tabular}

Berdasarkan tabel di atas dapat dilihat bahwa berdasarkan pencatatan kuesioner responden yang memiliki

3. Distribusi Variabel dari

Kurikulum

Berdasarkan Status Akademik

Responden

Distribusi Responden preklinik terhadap variabel dari kurikulum jenis kelamin laki-laki sebanyak $(30.5 \%)$ dan perempuan $(69.5 \%)$.

tersembunyi yang terdiri atas variabel profesionalisme, etika, altruisme, kepemimpinan, dan empati dapat dilihat pada Tabel 3.

Tabel 3. Distribusi Responden Preklinik

\begin{tabular}{|c|c|c|c|c|c|}
\hline \multirow{2}{*}{$\begin{array}{c}\text { Status } \\
\text { Akademik }\end{array}$} & \multirow{2}{*}{$\begin{array}{l}\text { Variabel Kurikulum } \\
\text { Tersembunyi }\end{array}$} & \multicolumn{2}{|c|}{ Hasil } & \multicolumn{2}{|c|}{ Persentase (\%) } \\
\hline & & $\mathbf{Y a}$ & Tidak & Ya & Tidak \\
\hline \multirow{5}{*}{$\begin{array}{l}\text { Mahasiswa } \\
\text { Preklinik }\end{array}$} & Profesionalisme & 136 & 0 & 100 & 0 \\
\hline & Etika & 134 & 2 & 98.5 & 1.5 \\
\hline & Altruisme & 134 & 2 & 98.5 & 1.5 \\
\hline & Kepemimpinan & 132 & 4 & 97 & 3 \\
\hline & Empati & 136 & 0 & 100 & 0 \\
\hline
\end{tabular}

Tabel 3 menunjukkan persentase dari pemahaman mahasiswa preklinik terkait kurikulum tersembunyi sebanyak $136 \quad(100 \%)$ memiliki pemahaman baik mengenai pembelajaran kurikulum tersembunyi pada variabel profesionalisme dan empati, 134 (98.5\%) mengetahui baik pembelajaran tentang altruisme dan kepemimpinan, dan 132 (97\%) mengetahui baik pembelajaran kepemimpinan. Berdasarkan Tabel 3 juga didapatkan jumlah dan persentase pemahaman tidak baik mengenai etika, altruisme, dan kepemimpinan masingmasing $2(1.5 \%), 2(1.5 \%)$, dan 4 (3\%).

Distribusi Responden Klinik terhadap variabel dari kurikulum tersembunyi yang terdiri atas variabel profesionalisme, etika, altruisme, kepemimpinan, dan empati dapat dilihat pada Tabel 4. 
Tabel 4. Distribusi Responden Klinik

\begin{tabular}{clcccc}
\hline $\begin{array}{c}\text { Status } \\
\text { Akademik }\end{array}$ & $\begin{array}{l}\text { Variabel Kurikulum } \\
\text { Tersembunyi }\end{array}$ & \multicolumn{2}{c}{ Hasil } & \multicolumn{2}{c}{ Persentase (\%) } \\
& & Ya & Tidak & Ya & Tidak \\
\cline { 2 - 5 } Mahasiswa & Profesionalisme & 31 & 0 & 100 & 0 \\
Klinik & Altra & 31 & 0 & 100 & 0 \\
& Kepemimpinan & 31 & 0 & 100 & 0 \\
& Empati & 27 & 4 & 87 & 13 \\
\end{tabular}

Tabel 4 di atas menunjukkan jumlah dan persentase mahasiswa klinik yang memahami dengan baik kurikulum tersembunyi yang diajarkan. Sebanyak 31 (100\%) mahasiswa klinik mengetahui baik pembelajaran kurikulum tersembunyi yang berkaitan dengan profesionalisme, etika, empati, dan altruisme sedangkan jumlah dan

\section{PEMBAHASAN}

Kurikulum

merupakan kurikulum yang tidak dipelajari akan tetapi diterapkan dan memberikan pengaruh dalam kehidupan. Kurikulum tersembunyi terdiri dari profesionalisme, etika, altruisme, empati, dan kepemimpinan. Penelitian ini bertujuan untuk mengetahui tingkat pemahaman mahasiswa pre-klinik dan mahasiswa klinik terkait pendidikan kurikulum tersembunyi pada Program Studi Pendidikan Dokter Fakultas Kedokteran Universitas Abulyatama. Berdasarkan hasil penelitian yang disajikan pada Tabel 1 menunjukkan distribusi responden berdasarkan status akademik dengan kategori mahasiswa pre-klinik dan mahasiswa klinik dengan jumlah responden yang memenuhi kriteria penelitian sebanyak 167 responden. Jumlah dan persentasenya yaitu sebesar $136(81.4 \%)$ responden mahasiswa preklinik, dan 31 (18.6\%) mahasiswa klinik. Pengkategorian status akademik dilakukan untuk mengetahui pemahaman yang dimiliki setiap responden berdasarkan status akademik mahasiswa pre-klinik, dan mahasiswa klinik,

Distribusi responden pada Tabel 2 menjelaskan jumlah responden

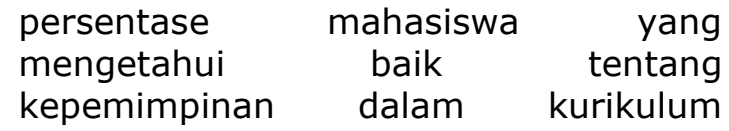
tersembunyi sebanyak 27 (87\%). Terdapat 4 (13\%) mahasiswa klinik yang tidak mengetahui baik tentang kepemimpinan pada kurikulum tersembunyi.

berdasarkan jenis kelamin laki-laki dan perempuan. Jumlah dan persentase responden berdasarkan jenis kelamin masing-masing sebesar 51 (30.5\%) Laki-laki dan 116 (69.5\%) perempuan. Hasil pengkategorian berdasarkan jenis kelamin didominasi pada perempuan sebanyak 116 koresponden. Pengkategorian berdasarkan jenis kelamin ini tidak terlalu berpengaruh terhadap pemahaman responden tentang kurikulum tersembunyi yang terdiri dari profesionalisme, altruisme, etika, empati dan kepemimpinan.

Temuan dalam penelitian ini sejalan dengan hasil penelitian terkait hubungan perbedaan gender dengan profesionalisme profesi auditor akuntan publik yang menunjukkan bahwa perbedaan jenis kelamin laki-laki dan perempuan tidak berpengaruh terhadap profesionalisme (Ikhsan, 2007). Sejalan dengan temuan tersebut, penelitian tentang hubungan perbedaan jenis kelamin dengan tingkat empati mahasiswa fakultas kedokteran di Universitas Papua di dapatkan hasil $p=$ 0.504 yang berarti tidak adanya hubungan perbedaan jenis kelamin dengan empati pada mahasiswa fakultas kedokteran Universitas Papua (Pinagsirih, et al., 2019) 


\section{KESIMPULAN}

Berdasarkan hasil penelitian yang dilakukan, dapat disimpulkan bahwa mahasiswa Program Studi Pendidikan Dokter Universitas Abulyatama dengan status akademi mahasiswa preklinik dan mahasiswa klinik memiliki tingkat pemahaman yang baik tentang kurikulum tersembunyi. Kurikulum tersembunyi yang dipahami mahasiswa dengan baik berkaitan tentang profesionalisme, kepemimpinan, altruisme, empati dan etika.

\section{SARAN}

Nurdin, S. (2018). Pengembangan kurikulum dan rencana pembelajaran semester (RPS) berbasis KKNI di perguruan tinggi. Al-Fikrah: Jurnal Manajemen Pendidikan, 5(1), 21-30. http://dx.doi.org/10.31958/jaf.v5i1 .813

Bahri, S. (2017). Pengembangan Kurikulum Dasar dan Tujuannya. Jurnal IImiah Islam Futura, 11(1), 15-34. doi:10.22373/jiif.v11i1.61

Andriaty, S. N., Findyartini, A., \& Werdhani, R. A. (2016). Studi Eksplorasi Kemungkinan Penyebab Kegagalan Mahasiswa dalam Uji Kompetensi Dokter Indonesia, Studi Kasus di Fakultas Kedokteran Universitas Abulyatama. Serambi PTK, 3(2), 1-12.

Alsubaie, M. A. (2015). Hidden curriculum as one of current issue of curriculum. Journal of Education and Practice, 6(33), 125-128.

Rajput, V., Mookerjee, A. L., \& Cagande, C. (2017). The contemporary hidden curriculum in medical education. MedEdPublish, 6. doi:10.15694/mep.2017.000155
Berdasarkan penelitian yang telah dilakukan, peneliti menyarankan studi terkait dengan kurikulum tersembunyi perlu untuk dikaji lebih lanjut dengan menggunakan sampel yang lebih besar dan mencakup mahasiswa pada tiap angkatan untuk memperoleh hasil yang lebih baik. Hasil dari penelitian ini juga diharapkan dapat menjadi sumber informasi dan bahan evaluasi bagi instansi pendidikan untuk dapat terus mempertahankan dan memperbaiki penerapan kurikulum tersembunyi pada instansi terkait.

\section{DAFTAR PUSTAKA}

Gardeshi, Z., Amini, M., \& Nabeiei, P. (2018). The perception of hidden curriculum among undergraduate medical students: a qualitative study. BMC research notes, 11(1), 271. doi:10.1186/s13104-0183385-7

Hafferty, F. W., Gaufberg, E. H., \& O'Donnell, J. F. (2015). The role of the hidden curriculum in "on doctoring" courses. AMA Journal of Ethics, 17(2), 129-137. doi:10.1001/virtualmentor.2015.17 .2.medu1-1502

Lawrence, C., Mhlaba, T., Stewart, K. A., Moletsane, R., Gaede, B., \& Moshabela, M. (2018). The hidden curricula of medical education: a scoping review. Academic medicine: journal of the Association of American Medical Colleges, 93(4), 648656.doi: $10.1097 /$ ACM. 0000000000 002004

Phillips, S. P., \& Clarke, M. (2012). More than an education: the hidden curriculum, professional attitudes and career choice. Medical education, 46(9), 887893.https://doi.org/10.1111/j.1365 $-2923.2012 .04316 . x$ 
Balboni, M. J., Bandini, J., Mitchell, C., Epstein-Peterson, Z. D., Amobi, A., Cahill, J., ... \& Balboni, T. (2015). Religion, spirituality, and the hidden curriculum: medical student and faculty reflections. Journal of pain and symptom management, 50(4), 507-515. https://doi.org/10.1016/j.jpainsym man.2015.04.020

Mossop, L., Dennick, R., Hammond, R., \& Robbé, I. (2013). Analysing the hidden curriculum: use of a cultural web. Medical education, 47(2), 134-143.

https://doi.org/10.1111/medu.120

72

Silveira, G. L., Campos, L. K., Schweller, M., Turato, E. R., Helmich, E., \& de Carvalho-Filho, M. A. (2019). "Speed up"! The influences of the hidden curriculum on the professional identity development of medical students. Health Professions Education, 5(3), 198-209.

https://doi.org/10.1016/j.hpe.2018 .07 .003

Yahya, M. S. (2013). Hidden Curriculum Pada Sistem Pendidikan Sekolah Tinggi Agama Islam Negeri (Stain) Purwokerto Tahun 2013. Jurnal Kependidikan, 1(1), 123-149. https://doi.org/10.24090/jk.v1i1.5 35

Gunawan, I., Kusumaningrum, D. E., Triwiyanto, T., Zulkarnain, W., \& Nurabadi, A. (2018, October). Pengaruh Kurikulum Tersembunyi terhadap Motivasi Diri Mahasiswa. In Prosiding Seminar Nasional Pendidikan, Tema: Mendidik Cerdas Generasi Digital, Fakultas IImu Pendidikan Universitas Negeri Malang, Malang (Vol. 4, pp. 90-97).
Ikhsan, A. (2007). Profesionalisme auditor pada kantor akuntan publik dilihat dari perbedaan gender, kantor akuntan publik dan hirarki jabatannya. Jurnal bisnis dan akuntansi, 9(3), 199-222.

Pinagsirih, M. H. D., Findyartini, A., \& Marpaung, N. L. E. (2019). Hubungan antara Jenis Kelamin dan Tingkat Akademik dengan Empati pada Mahasiswa Fakultas Kedokteran Universitas Papua (Doctoral dissertation, Fakultas Kedokteran Unipa). 